\title{
THE GENETICS OF TRISTYLY IN OXALIS VALDIVIENSIS
}

\author{
VIVIANE C. FYFE \\ Department of Genetics, Cambridge
}

Received 23.xi.49

ThE efficiency of tristyly as a crossbreeding system depends, as Fisher and Mather (1943) pointed out, on the equilibrium of the three forms in a population. The inheritance of these forms is, therefore, of considerable interest. In Lythrum salicaria, Fisher and Mather (I943) disproved East's theory of linked lethals, and demonstrated tetrasomic inheritance. The purpose of this paper is to report the differences and similarities found, during the course of work carried out at Cambridge since I946, in Oxalis valdiviensis, a wild species from Chile.

The three forms, which have been described by Darwin (I880) and Barlow (I9I3), differ in respect of the length of the style, the length of the two whorls of stamens, and the size of the pollen grains. Each form has two different lengths of stamens and a style of yet a third length, so that the anthers of the long-styled flowers are at the mid and short level, of the mid-styled form, at the long and short level, and, of the short-styled form at the long and mid level. For legitimate pollination it is essential that pollen from anthers of the same level as the style be used, each form can, therefore, be legitimately fertilised by both the other forms.

With both these species, Darwin showed that when illegitimate pollinations were made, i.e. using pollen from a different level to that of the style, which includes selfing, very few, if any, capsules resulted. With Oxalis valdiviensis, he quotes Hildebrand (I87I), who obtained 6 capsules from 255 pollinations with an average of 3.83 seeds. On the other hand, from i 38 legitimate pollinations, he obtained I 38 capsules with an average of I $\cdot 33$ seeds in each.

The facts established by C. Darwin (I880) and Barlow (I9I3 and I 923) were that the long-styled form is the recessive, since only long-styled plants were produced from illegitimate self-fertilisations and cross-fertilisations between two Longs; that two loci are involved -that for short style being epistatic to that for mid, so that shortstyled plants can carry the mid allele, showing this in their progeny, while mid-styled plants cannot carry the short gene.

This two-factor hypothesis, though first published by von Ubisch ( $192 \mathrm{I}$ ), was, in fact, the hypothesis on which Barlow had previously based her work published in I923 (see East, 1927). East's investigations on Lythrum led him to write, "One can hardly examine this 
evidence without feeling that the two-factor hypothesis is an approach to the truth. Yet it is not the whole truth." He then went on to postulate that " $\mathrm{Mid}$ is conditioned by duplicate linked factors, $\mathrm{M}_{a}$ and $\mathrm{M}_{b}$ that are lethal in the homozygous condition." In effect a three-factor hypothesis. It was only when Fisher and Mather (I940) showed the non-lethality of the mid factor, and, in 1942, polysomic inheritance, that the two-factor hypothesis, in its new form, was firmly established in respect of Lythrum.

Throughout our experiments we adopted the open pollination method used by Fisher and Mather (1943) in their experiments with L. salicaria. This consists of surrounding the plants to be fertilised by plenty of suitable legitimate pollen plants in an isolated plot, and allowing insects to do the pollinations. The proportion of stray pollen may be verified from the progenies, and in Lythrum was found to be only I per cent. of that available (Fisher and Mather, I943). It is interesting also that illegitimate unions occurring with appreciable frequency may be easily detected. An abundant supply of seed with the opportunity of growing sufficiently large progenies is the outstanding practical advantage.

\section{DISOMIC INHERITANCE}

To find out whether inheritance is disomic or polysomic the procedure of Fisher and Mather (I 943) in establishing tetrasomic inheritance in L. salicaria was followed.

Seed was obtained from the Botanic Garden in Cambridge in I 946. The resulting plants were classified for style length and twelve Shorts set out in an isolated plot and surrounded by sixteen longstyled plants as pollen parents. Seed was harvested from the Shorts and I 2 progenies of 120 each grown the following summer. These were scored for style-length (table I).

TABLE I

Progenies grown in 1947 testing 12 Shorts

\begin{tabular}{|c|c|c|c|c|c|c|c|c|c|}
\hline $\begin{array}{l}\text { Plant } \\
\text { Number }\end{array}$ & $\mathbf{L}$ & M & $\mathrm{S}$ & Total & $\begin{array}{c}\text { Plant } \\
\text { Number }\end{array}$ & $\mathrm{L}$ & $\mathrm{M}$ & $\mathrm{S}$ & Total \\
\hline $\mathrm{S}_{4} 6 . \mathrm{A}$ & 52 & $\ldots$ & 65 & 117 & $\mathrm{~S}_{4} 6 . \mathrm{B}$ & 8 & 49 & 62 & 119 \\
\hline $\mathrm{S}_{46 . \mathrm{G}}$ & 66 & $\ldots$ & $5^{I}$ & 117 & $\mathrm{~S}_{46 . \mathrm{C}}$ & 3 & $\begin{array}{l}79 \\
52\end{array}$ & 52 & 107 \\
\hline $\mathrm{S}_{46 . \mathrm{H}}$ & 62 & $\ldots$ & 60 & 122 & $\mathrm{~S}_{46 . \mathrm{D}}$ & 4 & $6_{I}$ & $5^{2}$ & 117 \\
\hline $\mathrm{S}_{46 . J}$ & $5^{2}$ & $\ldots$ & 46 & $9^{8}$ & $\mathrm{~S}_{4} 6 . \mathrm{E}$ & 2 & 63 & $5 \mathrm{I}$ & 116 \\
\hline \multirow{3}{*}{$S_{46 . L}$} & 71 & $\cdots$ & $4^{6}$ & II 7 & $S_{46} 6 . F$ & 3 & $5^{8}$ & 56 & 117 \\
\hline & 60 & $\ldots$ & $5^{I}$ & II I & $\mathrm{S}_{4} 6.1$ & 4 & $4^{6}$ & 63 & 113 \\
\hline & $3^{6} 3$ & $\ldots$ & $3^{19}$ & 682 & & 24 & $3^{29}$ & $33^{6}$ & 689 \\
\hline
\end{tabular}

The total absence of Mids in six of these progenies indicates, not only that the Short parents did not carry the mid gene, but also that little stray pollen was present at the crossing plot, nor did illegitimate unions take place between the Shorts, since the other six plants evidently do carry the mid gene. 
In 1947 three of the Shorts carrying the mid gene were crossed with their Mid daughters, which must be heterozygous for Mid (Mm) as their pollen parent was a Long. Table 2 shows the classification of the progenies of the three Shorts and the mixed seed from their Mid daughters.

TABLE 2

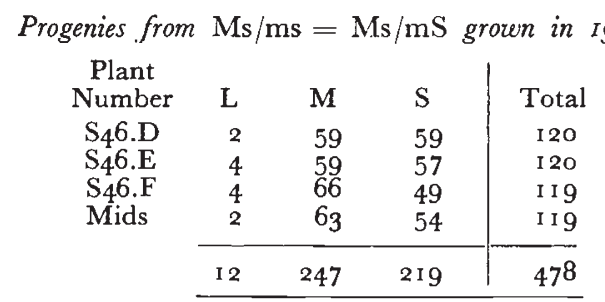

If inheritance is disomic, the Mid offspring from such a cross $(\mathrm{SsMm}=\mathrm{ssMm})$ are expected to be either homozygous $(\mathrm{MM})$ or heterozygous $(\mathrm{Mm})$, and when backcrossed to Long, their progenies would be of two types-one segregating I Long: I Mid and the other consisting entirely of Mids. Whereas if tetrasomy existed, the genotype of the six mid-carrying Shorts shown in table I would be $\mathrm{Ss}_{3} \mathrm{Mm}_{3}$ and their Mid daughters- $\mathrm{s}_{4} \mathrm{Mm}_{3}$. The Mids resulting from an intercross of these two genotypes would be duplex- $-\mathrm{M}_{2} \mathrm{~m}_{2}$, and simplex- $-\mathrm{Mm}_{3}$, in the proportion of $\mathrm{I}: 2$, and when backcrossed to Long, the duplex would segregate 5 Mids : I Long, while the simplex would give I $\mathrm{M}: \mathrm{I} \mathrm{L}$. A third class might occur by double reduction, as was the case in L. salicaria (Fisher and Mather, I943), when a triplex Mid $-\mathrm{M}_{3} \mathrm{~m}$ appeared. When this plant was backcrossed, almost all its offspring were Mids, the Longs that appeared being due to double reduction. It is apparent, then, that only when inheritance is disomic can any considerable fraction of the progenies of Mids obtained from the intercross described above be expected to contain only Mids.

Twelve Mids, obtained from the intercross of $\mathrm{S}_{4} 6 . \mathrm{D}, \mathrm{S}_{4} 6 . \mathrm{E}$ and $\mathrm{S}_{4} 6 . \mathrm{F}$ with their Mid daughters, were backcrossed to Longs, and in I949 progenies of 30 were grown and classified for style length. As will be seen from table 3 , seven gave no Longs and are presumably homozygous, while the other five segregated I : I.

TABLE 3

Test of 12 Mids in 1949

\begin{tabular}{|c|c|c|c|c|c|c|c|}
\hline $\begin{array}{c}\text { Plant } \\
\text { Number }\end{array}$ & $\mathrm{L}$ & $\mathbf{M}$ & Total & $\begin{array}{c}\text { Plant } \\
\text { Number }\end{array}$ & $\mathrm{L}$ & $\mathbf{M}$ & Total \\
\hline $\begin{array}{l}\mathbf{M}_{48.73} \\
\mathbf{M}_{48.76} \\
\mathbf{M}_{48.78} \\
\mathbf{M}_{48.81} \\
\mathbf{M}_{48.82}\end{array}$ & $\begin{array}{l}13 \\
15 \\
17 \\
17 \\
19\end{array}$ & $\begin{array}{l}17 \\
15 \\
13 \\
13 \\
\text { II }\end{array}$ & $\begin{array}{l}30 \\
30 \\
30 \\
30 \\
30\end{array}$ & $\begin{array}{l}M_{48.72} \\
M_{48.74} \\
M_{48.75} \\
M_{48.77} \\
M_{48.79} \\
M_{48.80} \\
M_{48.83}\end{array}$ & $\begin{array}{l}\ldots \\
\ldots \\
\ldots \\
\ldots \\
\ldots \\
\ldots \\
\ldots\end{array}$ & $\begin{array}{l}28 \\
30 \\
30 \\
30 \\
30 \\
30 \\
30\end{array}$ & $\begin{array}{l}28 \\
30 \\
30 \\
30 \\
30 \\
30 \\
30\end{array}$ \\
\hline 5 plants & $8 \mathbf{r}$ & 69 & 150 & 7 plants & $\ldots$ & 208 & 208 \\
\hline
\end{tabular}




\section{LINKAGE OF MID AND SHORT LOCI}

It will be seen from table I that, in the six progenies containing Mids, the ratio of Mid to Long is not the I : I expected with independence. All six progenies are, however, homogeneous, $\chi^{2}=6.77$ for 5 degrees of freedom. The short to non-short ratio is homogeneous- $\chi^{2}=4.72$ for 5 d.f. The simplest explanation for this unexpected ratio is that the mid and short loci are linked and that these six Short plants are all in repulsion- $\mathrm{Sm} / \mathrm{sM}$, which when backcrossed to Longs are expected to give mostly Shorts and Mids. Any Longs would be recombinants. The other recombinant class would be short-styled plants carrying the mid gene in coupling$\mathrm{SM} / \mathrm{sm}$. Since the proportion of Longs is 6.79 per cent. of the nonshorts, a similar proportion, i.e. I in $\mathrm{I} 5$, of the Shorts can be expected to be of the genotype $\mathrm{SM} / \mathrm{sm}$. It was, therefore, decided to test I 5 Shorts from these progenies by backcrossing to Longs, and in 1948 , progenies of 100 from each Short were grown and scored for style length.

The results obtained are given in table 4. Fourteen progenies gave no Mids. $\mathrm{S}_{47.4}$, however, gave 2 Mids out of 27 non-shorts. The following year a progeny of 995 was grown from this plant. 528 Longs, 23 Mids and 444 Shorts were obtained. The proportion of Mids in the non-shorts represents the recombination fraction, and is rather less than was observed in the six progenies grown in 1947.

TABLE 4

Test of ${ }^{15}$ Shorts in 1948

\begin{tabular}{|c|c|c|c|c|c|c|c|c|c|}
\hline $\begin{array}{c}\text { Plant } \\
\text { Number }\end{array}$ & L & $\mathbf{M}$ & $\mathbf{S}$ & Total & $\begin{array}{c}\text { Plant } \\
\text { Number }\end{array}$ & L & $\mathbf{M}$ & $\mathrm{S}$ & Total \\
\hline$S_{47 \cdot 4}$ & 25 & 2 & $3^{8}$ & 65 & $\begin{array}{l}S_{47.1} \\
S_{47.2} \\
S_{47.3} \\
S_{47.5} \\
S_{47.6} \\
S_{47.7} \\
S_{47.8} \\
S_{47.9} \\
S_{47.10} \\
S_{47.11} \\
S_{47.12} \\
S_{47.13} \\
S_{47.14} \\
S_{47.15}\end{array}$ & $\begin{array}{l}54 \\
54 \\
50 \\
39 \\
57 \\
56 \\
45 \\
46 \\
50 \\
51 \\
53 \\
56 \\
60 \\
51\end{array}$ & $\begin{array}{l}\ldots \\
\ldots \\
\ldots \\
\ldots \\
\ldots \\
\ldots \\
\ldots \\
\ldots \\
\ldots \\
\ldots \\
\ldots \\
\ldots\end{array}$ & $\begin{array}{l}45 \\
46 \\
50 \\
6 \mathrm{I} \\
43 \\
44 \\
55 \\
55 \\
50 \\
48 \\
48 \\
42 \\
39 \\
49\end{array}$ & $\begin{array}{r}99 \\
100 \\
100 \\
100 \\
100 \\
100 \\
100 \\
101 \\
100 \\
99 \\
101 \\
98 \\
99 \\
100\end{array}$ \\
\hline I plant & 25 & 2 & $3^{8}$ & 65 & 14 plants & 722 & $\ldots$ & 675 & 1397 \\
\hline
\end{tabular}

Using the method of maximum likelihood, the estimate of the recombination fraction, obtained from all the data, is 5.74 per cent. The amount of information is 19832.6 from which is derived a standard error of $0.7 \mathrm{I}$ per cent. On the whole this is an estimate of recombination in the ovules, since the only pollen mother cells tested were of the Mids in table 2, which contributed little to the estimate. 


\section{FREQUENCIES OF THE 7 GENOTYPES}

Short plants are always heterozygous in respect of the short allele, as a homozygote would only be produced by an illegitimate selfing or mating of Short with Short. In respect of their Mid content, however, Shorts may be any ine of four genotypes. Mids are of two genotypes, and Longs of only one, the double recessive.

Assuming that the three forms are present in equal numbers in a population, with equal viability and fertility, the seven genotypic frequencies, whrn in equilibrium, would be-

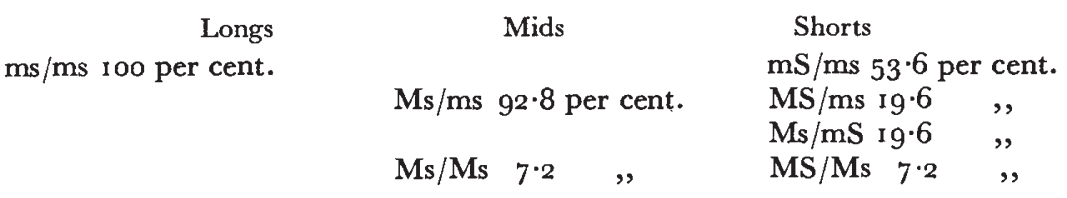

\section{COMPARISON WITH LYTHRUM}

The striking similarities in the hereditary mechanism of tristyly in Lythrum salicaria and Oxalis valdiviensis are that the long-styled form is the double recessive, and that the mid gene is l.ypostatic to the Short. The differences are that $L$. salicaria is an autotetraploid with 60 chromosomes, forming some quadrivalents at meiosis, and showing tetrasomic inheritance, whereas $O$. valdiviensis is a diploid forming 9 bivalents and showing disomic inheritance : that the mid and short loci are independent in the former and linked in the latter. Fisher (1949) has shown that this linkage confers a slight advantage in that it makes inbreeding by sib-matings a little less likely to occur; but it does not reduce the frequency of parent-offspring matings.

In Lythrum there has been a regular excess of Mids in progenies where I Mid to I Long is expected. In the Oxalis progenies containing short-styled plants, it will be seen that out of a total of 4306 plants only 2030 are Shorts, where half are expected. Although the deficiency of Shorts is less than 6 per cent., it is significant $-\chi^{2}=14.05$ for I degree of freedom. All except I 9 of these plants had Short mothers, so the possibility that this is a reciprocal difference cannot be ruled out. The I I 9 plants with Mid mothers (table 2) show a 4 per cent. deficiency of Shorts, but this is not significantly different from the I : I expected. After discussing this with Dr A. R. G. Owen, it became apparent that the observed deficiency would be quite compatible with a situation in which Ss zygotes had a viability of only 94 per cent. relative to ss zygotes. On account of the compulsory crossbreeding, such a disadvantage of one genotype relative to the other would not lead to the extinction of one of the alleles, and might well, in a wild population, lead to a stable proportion of these genotypes in the same ratio, i.e. of the viability.

In making this comparison, it is as well to note, however, that, 
with the exception of the parent-offspring mating of three Shorts to their Mid daughters (table 2), no appreciable inbreeding has been done during the work on Oxalis, whereas, in Lythrum there was a considerable amount of inbreeding.

The genus Oxalis is a large one. In his taxonomic revision of the genus, Salter (1944) describes over 200 species in South Africa alone. Since almost all of them are tristylic, it would seem reasonable to assume that tristyly developed in their common ancestor rather than in each species independently or even in each group of species. They have, however, various chromosome numbers ranging from 10 to 80 -Darlington and Janaki Ammal (1945) give the basic numbers 5, $6,7,9$, and 11 -many of them are presumably polyploids. It is hoped that the experimental work may be extended on other species of Oxalis.

\section{SUMMARY}

I. Tristyly is a crossbreeding system. A knowledge of the inheritance of the long-, mid- and short-styled forms is required to show how this system works.

2. That the long form is recessive was shown by Darwin and confirmed by Barlow, who based her experiments on the assumption of a short gene and a mid gene, the former being epistatic to the latter.

3. In this investigation of the situation in Oxalis valdiviensis the open pollination method of Fisher and Mather was used in all crosses. Contamination and illegitimate unions were so rare that none was detected.

4. Twelve Shorts were crossed to Longs. Six of them were found to be carrying the mid gene. Three of these mid-carrying Shorts were then crossed to their Mid daughters, which were necessarily heterozygotes. Twelve Mids resulting from this intercross were tested by backcrossing to Longs. Five segregated I Long : I Mid, and seven gave no Longs and must, therefore, be homozygous Mids, thus showing that the inheritance of Mid is disomic.

5. The 6 mid-carrying Shorts detected from the first cross gave satisfactory I Short: I Non-short ratios. The Long: Mid ratio was I : 14 with a homogeneity $\chi^{2}$ of 4.72 for 5 d.f., suggesting linkage of the mid and short loci, with all six Shorts in repulsion. Half the recombinants would be Longs, the other half would be Shorts carrying the mid gene in coupling. Fifteen Shorts were, therefore, tested by backcrossing to Longs. Fourteen gave no Mids in their progenies, but one gave 2 Mids out of 27 non-shorts, and in the following year, 23 out of $55^{\mathrm{I}}$ non-shorts.

6 . The recombination fraction estimated by maximum likelihood on all the data is 5.74 per cent. with standard error $0.7 \mathrm{r}$ per cent. This estimate is based mainly on the recombination in the ovules. 
7. Taking into account coupling and repulsion, there are seven genotypes. Four are phenotypically Shorts, two are Mids and one Long. The frequencies of the seven genotypes are given, assuming equal numbers of each phenotype with equal viability and fertility.

8. A comparison is made with the similar tristyly in $L$. salicaria.

I am greatly indebted to Professor R. A. Fisher for his collaboration throughout these experiments.

\section{REFERENCES}

Barlow, N. 1913. Preliminary note on heterostylism in Oxalis and Lythrum. $\mathcal{7}$. Genet., 3, 53-65.

BARLOW, N. Ig23. Inheritance of the three forms in trimorphic species. F. Genet., 13, $133-146$.

Darlington, C. D., AND JANaki ammal, E. K. 1945. Chromosome Atlas of Cultivated Plants. London : Allen \& Unwin.

DARWIN, c. I880. The Different Forms of Flowers on Plants of the Same Species. London : Murray.

EAST, E. M. 1927. The inheritance of heterostyly in Lythrum salicaria. Genetics, $12,393-414$.

FISHER, R. A. I949. The Theory of Inbreeding. Edinburgh : Oliver \& Boyd.

FISHER, R. A., AND MATHER, $\mathrm{K}$. I943. The inheritance of style length in Lythrum salicaria. Ann. Eugen., 12, I-23.

FISHER, R. A., AND MATHER, K. 1942. Polyploid inheritance in Lythrum salicaria. Nature, Lond., 150, 430 .

PISHER, R. A., AND MATHER, K. 1940. Non-lethality of the Mid factor in Lythrum salicaria. Nature, Lond., 146,521 .

HILDEBRAND, F. 1871. Experimente und Beobachtungen an einigen trimorphen Oxalis-Arten. Bot. Zeit., 29, 416-425.

SAlter, Gaptain (s.) T. M. 1944. The Genus Oxalis in South Africa, a Taxonomic Revision. J. S. African Bot., Suppl. Vol. No. I.

UBISCH, G. vON. I921. Zur Genetik der trimorphen Heterostylie sowie einige Bemerkungen zur dimorphen Heterostylie. Biol. Centralbl., $4^{I}, 88-96$. 